\title{
Evaluation of immunoblotting test results in patients with positive antinuclear antibodies
}

\section{Antinükleer antikorların pozitif saptandığı hastalarda immunoblotting test sonuçlarının değerlendirilmesi}

\author{
Demet GÜR VURAL ${ }^{1}$ (ID), Yeliz TANRIVERDi ÇAYCI ${ }^{1}$ (ID), İlknur BIYIK' (ID), Kemal BíLGiN¹ (ID), \\ Asuman BiRINCi1 (ID)
}

\section{ABSTRACT}

Objective: Autoimmune diseases occur as a result of the immune response to self antigens and tissues of the organism and the detection of autoantibodies is very important in the diagnosis of these disorders. Antinuclear antibodies (ANA) autoantibodies generated against to nuclear/ cytoplasmic components of the cell are important diagnostic criteria for connective tissue diseases. Currently, a number of methods are available for the detection of ANA. The gold standard method for the detection of ANA is Indirect Immunofluorescence Antibody (IIFA) assay using Hep2 (human laryngeal epidermoid carcinoma). When positive results are observed, Extractable Nuclear Antigen( ENA) tests follow as a means of confirming the diagnosis. Identification of the specific extractable nuclear antigens is warranted because this may further differentiate between the distinct types of autoimmune connective tissue diseases. In this study, were analyzed retrospectively that ENA test results in patients with positive ANA IIFA test.

Methods: Antinuclear antibodies were tested for a total of 3000 patients admitted to various clinics of Ondokuz Mayıs University Medical Faculty. Each serum sample was studied at 1: 100 dilution in accordance with the
\end{abstract}

\section{ÖZET}

Amaç: Otoimmün hastalıklar, organizmanın kendi doku ve hücrelerine karșı immün yanıt gelișmesi sonucu olușmaktadır ve bu hastalıkların tanısında otoantikorlar büyük önem tașımaktadır. Anti nükleer antikor (ANA) adı verilen, hücre nükleusu ve/veya sitoplazmasındaki nükleer yapılara karșı gelișen otoantikorlar, bağ doku hastalıklarında önemli bir tanı kriteridir. Günümüzde, ANA pozitifliğinin saptanması amacıyla geliștirilmiş bir çok yöntem bulunmaktadır. ANA tespiti için altın standart yöntem, Hep2 (insan laryngeal epidermoid karsinoma) hücreleri kullanılarak gerçekleștirilen Indirekt Immünofloresan Antikor (IIFA) testidir. Pozitif sonuçlar gözlendiğinde, tanıyı doğrulamanın bir yolu olarak, ekstrakte edilebilir nükleer antijen (ENA) testleri takip eder. Spesifik ekstrakte edilebilir nükleer antijenlerin tanımlanması, otoimmün bağ dokusu hastalıklarının farklı tipleri arasındaki ayrımı sağlayabilir. Bu çalıșmada, ANA IIFA testi pozitif olan hastalarda ENA test sonuçlarını retrospektif olarak inceledik.

Yöntem: Ondokuz Mayıs Üniversitesi Tıp Fakültesi'nin çeșitli kliniklerine bașvuran toplam 3000 hasta için Anti nükleer antikorlar test edildi. Her serum numunesi 1: 100 dilüsyonda

\footnotetext{
* This manuscript, presented as a paper poster at the International XXXVIII. Turkish Microbiology Congress.

'Ondokuz Mayıs University, Faculty of Medicine, Department of Medical Microbiology, Samsun
}

İletişim / Corresponding Author : Demet GÜR VURAL

DOI ID : 10.5505/TurkHijyen.2021.24482

Gür Vural D, Tanrıverdi Çaycı Y, Bıyık I, Bilgin K, Birinci A. Evaluation of immunoblotting test results in patients with positive antinuclear antibodies. Turk Hij Den Biyol Derg, 2021; 78(4): 443 - 450 
manufacturer's recommendations (Euroimmun AG, Lübeck, Germany) and staining pattern with fluorescence intensity was evaluated with immunofluorescence microscope. ENA was investigated by immunoblotting method (Euroimmun AG, Lübeck, Germany) in 640 ANA positive sera.

Results: Distribution of the patients included in the study, 2192 (73.07\%) were female and 808 (26.93\%) were male. 640 samples detected as ANA positive. When we look at the distribution of ANA patterns in positive samples; granular 173 (27.03\%), granular and cytoplasmic granular 98 (15.31\%), homogenous and granular 67 (10.47\%) were the most common. When the ENA profiles of the ANApositive samples were examined, 557 (83.7\%) were found to be positive and $83(12.97 \%)$ were negative. According to our study, SSA (26.88\%), SSB (17.81\%), Sm / RNP (17.66\%) were the first three places in the ENA positivite.

Conclusion: Our ANA positivity rate was found to be compatible with the literature. The pattern distribution is similar to the data of our region. After the first screening with IIFA, looking for different antigens with the immunoblot test; not only it is a cost effective approach;but also facilitate the diagnosis of autoimmune diseases.

Key Words: ANA (AntinuclearAntibody), Indirect Immunofluorescence Antibody (IIFA), Extractable Nuclear Antigen (ENA) üreticinin (Euroimmun $\mathrm{AG}$, Lübeck, Germany) önerileri doğrultusunda çalıșılmıș, immunfloresan mikroskopta boyanma paterni ve floresans şiddeti değerlendirilmiștir. ANA pozitif olarak tespit edilen 640 numunede immunoblot yöntemi (Euroimmun AG, Lübeck, Germany) ile ENA test edilmiștir.

Bulgular: Çalıșmaya alınan hastaların 2192'si $(\% 73,07)$ kadın, 808'i $(\% 26,93)$ erkekti. 640 numune ANA pozitif olarak tespit edilmiștir. Pozitif örneklerde ANA paternlerinin dağılımına baktığımızda;173 granüler $(\% 27,03)$, 98 granüler+sitoplazmik granüler $(\% 15,31)$, 67 homogen+granüler $(\% 10,47)$ en sık saptanmıștır. ANA pozitif örneklerin ENA profilleri incelendiğinde 557'si $(\% 83,7)$ pozitif, 83'ü $(\% 12,97)$ negatif bulundu. ENA pozitifliklerinde ilk üç sırayı SSA $(\% 26,88)$, SSB $(\% 17,81)$, Sm/RNP $(\% 17,66)$ aldı.

Sonuç: ANA pozitiflik oranımız literatür ile uyumlu bulunmuștur. Patern dağılımı da bölgemiz verilerine benzerdir. IIFA ile ilk tarama ardından immunoblot test ile farklı antijenlere bakılması; maliyet etkin bir yaklașım olmakla birlikte; otoimmün hastalıkların tanısını kolaylaștıracaktır.

Anahtar Kelimeler: ANA (Antinükleer antikor), İndirekt İmmunfloresan antikor (IIFA), Ekstrakte Edilebilir Nükleer Antijen (ENA)

\section{INTRODUCTION}

Antinuclear antibodies (ANA) are originally referred to autoantibodies that produced against nuclear antigens and some other antigens that present in the cell cytoplasm or membrane (1). The presence of ANA is used as a screening test for the diagnosis of autoimmune diseases especially for rheumatologic disorders. Approximately $25 \%$ of the community has ANA positivity but the prevalence of significantly elevated levels is about $2.5 \%$ which indicates an autoimmune disease. The gold standard for the 
detection of ANA is indirect immune fluorescence assay (IIFA) that has a lot of advantages like the detection of patterns which indicate certain diseases $(2,3,4)$. However, it is labour-intensive, and technical interpretation of the results can be subjective (5).

Some proteins found in the nucleus of the cell can be extracted using saline, and are called Extractable Nuclear Antigens (ENAs). Among ENAs, Smith (Sm) antigen is a nonhiston acidic ribonucleoprotein with low molecular weight; SS-A is a protein playing role in the process of mRNA, SS-B is a phosphoprotein playing role as a cofactor for RNA polymerase III; Scl-70 antigen is defined as DNA topoisomerase I, and Jo-1 is the histidyl-tRNA synthetase enzyme (6). Analysis of the reactivity to ENAs may be of help to distinguish between the different types of autoimmune connective tissue diseases (7). It is known that, presence of antibodies against the Smith (Sm) antigen are specific for SLE (8), and the presence of antiSjogren's Syndrome (SS)A and/or-SSB antibodies are a sign for Sjogren's Syndrome $(9,10)$. In addition to having diagnostic potential, detection of anti-ENA antibodies is prognostically significant, too. Presence of anti-SSA in the circulation of the pregnant woman might cause neonatal lupus erythematosus and/or congenital heart block in the newborn $(11,12)$, and presence anti- of Topo-I antibodies anticipates a more serious course of disease in systemic sclerosis (SSc) (13). In this study, it is aimed to evaluate extractable nuclear antigen test results in patients who were determined positive for anti-nuclear antibody, retrospectively.

\section{MATERIAL and METHOD}

Ondokuz Mayıs University Clinic Researchs Ethic Committee approval (Date: 01.10.2021 and Number: B.30.2.ODM.0.20.08/579) was obtained for this study.

ANA and anti ENA test results were retrospectively evaluated from clinical samples sent to Medical Microbiology Laboratory between January 2016December 2018.
Antinuclear antibodies were tested for a total of 3000 patients admitted to various clinics of Ondokuz -Mayıs University Medical Faculty. Each serum sample was dilueted as 1:100, and the presence of ANA and pattern was evaluated with ANA-IFA. The commercial IIFA kit (Euroimmun AG, Lübeck, Germany), which contains HEP-2 and monkey liver cells together as a tissue for ANA IIFA testing, was used. In accordance with the manufacturer's recommendations, patient serum were studied with 1/100 dilution titers. Prepared preparations were evaluated at a fluorescence microscope (Euroimmun AG, Lübeck, Germany) at a magnification of 400x. The results were reported qualitatively $(+,++,+++,++++)$ according to the fluorescence intensity of the slides and their patterns.

The samples that were detected as ANA positive subsequently tested for ENA. Samples were stored at $-20^{\circ} \mathrm{C}$ till the study. A total of 640 ANA-positive samples were tested for anti-ENA using. Anti-ENA profile immunoblot method (Euroimmun AG, Lübeck, Germany) was studied.

\section{RESULTS}

Of the patients included in the study, 2192 (73.07\%) were female and 808 (26.93\%) were male.

The distribution of the clinics as follows; rheumatology 1285 (42.83\%), physical therapy 345 $(11.5 \%)$ and hematology 213 (7.10\%)(Table 1). Total of 640 (21.33\%) serum samples were found to be positive for ANA IIFA. The distribution of ANA patterns in positive samples; speckled $n=173(27.03 \%)$, speckled and cytoplasmic granular $n=98(15.31 \%)$, homogen and speckled $n=67(10.47 \%)$ were the most common (Figure 1and Figure 2). It was detected that 557 (83.7\%) ENA positive and 83 (12.97\%) ENA negative in ANA positive patients. The ENA profiles of the ANApositive samples were; SSA $(26.88 \%)$, SSB $(17.81 \%)$, Sm / RNP (17.66\%) were the firstthree places in the ENA positivity (Table 2 ). 
Table 1. Distribution of the clinics

\begin{tabular}{|c|c|}
\hline Clinic & Number(\%) \\
\hline Pediatric Nephrology & $31(1,03)$ \\
\hline Child Health and Diseases & $49(1,63)$ \\
\hline Internalmedicine & $82(2,73)$ \\
\hline Dermatology & $123(4,10)$ \\
\hline InfectiousDiseases & $30(1,00)$ \\
\hline Physical Medicine and Rehabilitation & $345(11,50)$ \\
\hline Gastroenterology & $59(1,97)$ \\
\hline Chest Diseases & $180(6,00)$ \\
\hline Eye diseases & $161(5,37)$ \\
\hline Hematology & $213(7,10)$ \\
\hline Nephrology & $113(3,77)$ \\
\hline Neurology & $187(6,23)$ \\
\hline Rheumatology & $1285(42,83)$ \\
\hline Pediatrics Other ${ }^{1}$ & $36(1,2)$ \\
\hline Other ${ }^{\star 2}$ & $106(3,53)$ \\
\hline
\end{tabular}

Pediatrics Other*1: PediatricAllergy, PediatricSurgery, PediatricEndocrinology, Pediatriclnfection, PediatricGastroenterology, PediatricHematology, Pediatriclmmunology, PediatricCardiology, PediatricNeurology, Newborn.

Other*2: Emergency, Anesthesiology, Neurosurgery, Endochrinology, General Surgery, Thoracic Surgery, Gynecology and Obstetrics, Cardiovascular Surgery, Cardiology, Otorhinolaryngology, Oncology, Orthopedics andTraumatology, Psychiatry, Urology, Intensive Care Unit.

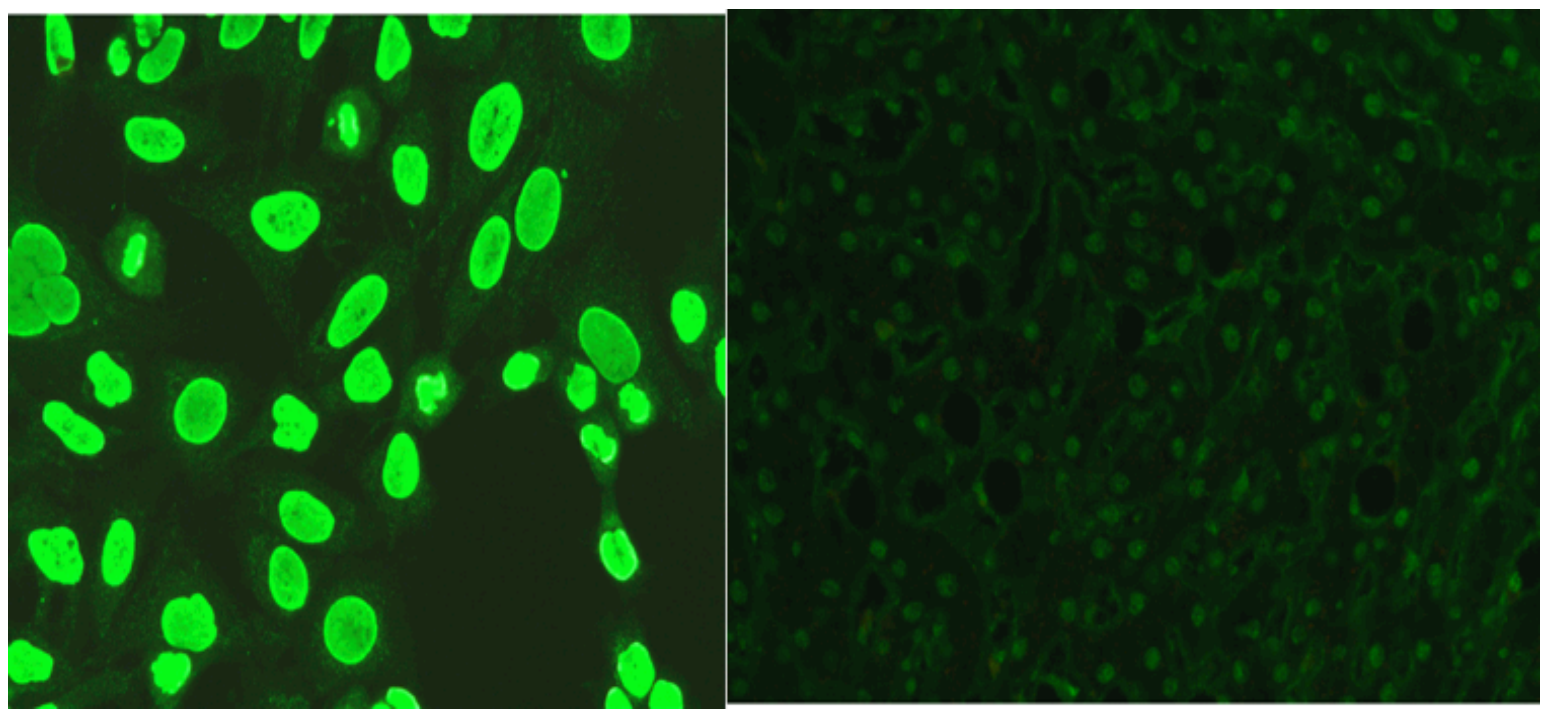

Figure 1. Homogen pattern in Hep-2 (x400) and liver tissue 


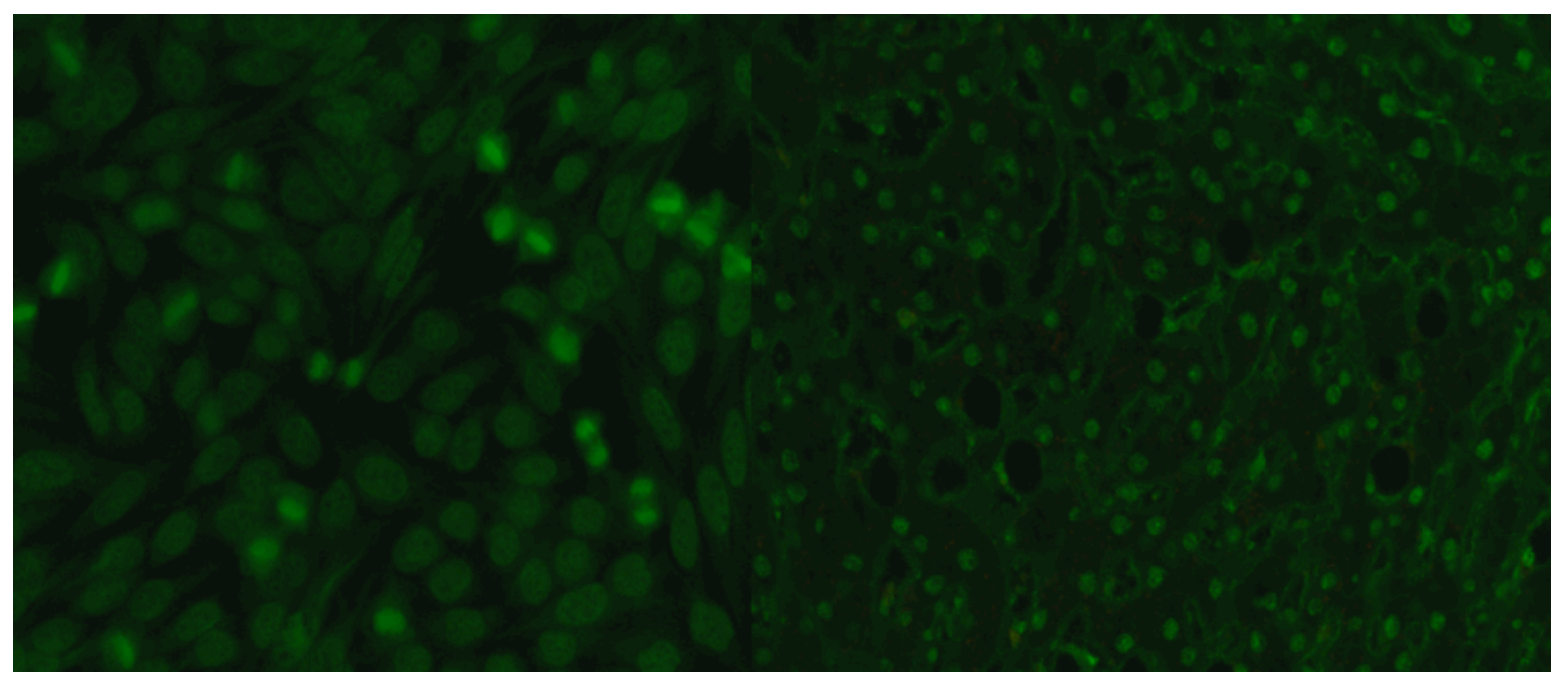

Figure 2. Homogen + speckled pattern in Hep-2 (x40) and liver tissue

Table 2. Comparison of ANA patterns and ENA profiles of the patients

\begin{tabular}{|c|c|c|c|c|c|c|c|c|c|}
\hline & & \multicolumn{8}{|c|}{ ENA } \\
\hline & & $\begin{array}{l}\text { Anti Scl- } \\
70\end{array}$ & $\begin{array}{l}\text { Anti } \\
\text { JO-1 }\end{array}$ & Anti-ss-A & Anti-ss-B & $\begin{array}{l}\text { Anti Sm/ } \\
\text { RNP }\end{array}$ & Anti-Sm & Total & $\%$ \\
\hline \multirow{14}{*}{ 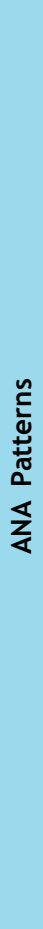 } & Homogen+Speckled & 10 & 10 & 10 & 12 & 16 & 9 & 67 & $10,47 \%$ \\
\hline & $\begin{array}{l}\text { Cytoplasmic granular + } \\
\text { Nuclear membrane }\end{array}$ & 3 & 1 & 2 & 5 & 1 & 2 & 14 & $2,19 \%$ \\
\hline & Speckled & 13 & 25 & 50 & 29 & 32 & 24 & 173 & $27,03 \%$ \\
\hline & $\begin{array}{l}\text { Speckled + } \\
\text { Cytoplasmic granular + } \\
\text { Homogen }\end{array}$ & 5 & 0 & 1 & 2 & 4 & 3 & 15 & $2,34 \%$ \\
\hline & $\begin{array}{l}\text { Speckled + } \\
\text { Dense fine speckled }\end{array}$ & 2 & 5 & 5 & 4 & 1 & 2 & 19 & $2,97 \%$ \\
\hline & Homogen & 3 & 1 & 4 & 0 & 4 & 2 & 14 & $2,19 \%$ \\
\hline & $\begin{array}{l}\text { Speckled + } \\
\text { Cytoplasmic granular }\end{array}$ & 3 & 8 & 39 & 17 & 17 & 14 & 98 & $15,31 \%$ \\
\hline & Nucleolar & 2 & 1 & 3 & 1 & 3 & 1 & 11 & $1,72 \%$ \\
\hline & Speckled + Nucleolar & 0 & 2 & 18 & 9 & 1 & 3 & 33 & $5,16 \%$ \\
\hline & Cytoplasmic granular & 0 & 8 & 3 & 4 & 2 & 3 & 20 & $3,13 \%$ \\
\hline & Other & 18 & 8 & 22 & 16 & 19 & 10 & 93 & $14,53 \%$ \\
\hline & Negative & 9 & 13 & 15 & 15 & 13 & 18 & 83 & $12,96 \%$ \\
\hline & Total & 68 & 82 & 172 & 114 & 113 & 91 & 640 & $100,00 \%$ \\
\hline & $\%$ & $10,63 \%$ & $12,81 \%$ & $26,88 \%$ & $17,81 \%$ & $17,65 \%$ & $14,22 \%$ & $100,00 \%$ & \\
\hline
\end{tabular}




\section{DISCUSSION and CONCLUSION}

The autoantibodies which are seen in autoimmune diseases are against to nuclear and cytoplasmic components of the cells (13). Early detection of autoantibodies has always played an important role in predicting and diagnosing autoimmune disorders, especially for the patients suspected with overlapped syndromes and complex conditions. Antinuclear antibodies (ANA), as detected by indirect immunofluorescence, are hallmarks of autoimmune connective tissue diseases. Identification of the specificity for extractable nuclear antigens (ENA) is warranted because this may further differentiate between the distinct types of autoimmune connective tissue diseases (7).

The presence of Antinuclear antibody is more common in women. Sex hormones (especially estrogens) play a significant role in the development of autoimmune diseases and predispose the female sex to more frequent occurrence of these diseases (14). This results with the knowledge of the autoimmune diseases are more frequent in women $(13,15,16,17)$. And in this study, the majority of the patients with suspected autoimmune disease were women $(73.07 \%)$.

In our study, most of the samples were sent from the rheumatology department $(42.83 \%)$ to our laboratory with the suspicion of autoimmune disease. This result is similar with the study of Karakeçe et al. (18).Likewise; in the study of Çelikbilek et al., they found the most common positivity in rheumatology department (17). Since autoantibodies has played a consolidate role in diagnosis of systemic autoimmune disorder, it is expectable that positivity rates are higher in the samples of the patient admits to of rheumatology department.

Anti-nuclear antibodies (ANA) represent important diagnostic markers in various autoimmune rheumatic conditions (e.g., systemic lupus erythematosus (SLE), Sjögren's syndrome, systemic sclerosis, dermato/ poly myositis, mixed connective tissue diseases, and rheumatoid arthritis), with an increasingly recognized relevance to disease prediction and prognosis (13). In our study, ANA positivity rate was found to be $21.33 \%$. ANA positivity rates were reported to be between $8-35 \%$ in Turkey $(13,19)$.

The American College of Rheumatology (ACR) and international committees recommend HEp2 IIF as the Standard screening method for ANA detection $(4,5,21)$. Up to 30 different ANA staining patterns have been described today including both nuclear as well as cytoplasmic staining patterns. The most common patterns include the homogeneous, speckled, nucleolar, and centromere pattern(7). This study, when the positivity of patients with ANA IIFA was examined, the highest observed ANA pattern was found to be speckled. In the study from Trabzon province, Kaklıkkaya et al. found that the most common pattern was speckled pattern similar like our study (21). This result is similar to the literature $(16,17,20,23)$.

Identification of the specificity for extractable nuclear antigens (ENA) is provided because this may further differentiate between the distinct types of autoimmune connective tissue diseases. At the same time some of ANA patterns are very rare and most technicians in routine laboratories are not trained to distinguish them all. (7). In our study, ENA positivity was found in $83.7 \%$ of ANA IIFA positive samples. Yumuk et al. found $79.5 \%$ ANA positivity in their study (23). According to our study, SSA (26.88\%), SSB (17.81\%), Sm / RNP (17.66\%) were the first three places in the ENA positivity in ANA-positive samples. According to the results of ENA test that Afșar et al. performed in ANA positive patients in 2007, they detected at least one antigen in 171 of 215 (79.5\%) patients and antibodies against the SS-A/Ro-52 antigen were the most common antibodies(3). Also, Yumuk et al. detected antigen positivity with ENA in 126 (60.5\%) of 208 ANA positive patients and antibodies against SS-A antigen were the most. (23)

In our study, no antigen was detected in ENA test in $12.97 \%$ of ANA positive patients. Antibodies against 
seven antigens are sought in our test strip. Therefore, there may be antibody positivity to antigens other than the seven antigens we studied. The presence of other antigens should be considered in the presence of clinical suspicion in patients who have been positively detected by the IIFA test and whose ENA test is negative.
In conclusion, ANAIIFA should be used as a screening test for suspected autoimmune disease. ENA testing should be performed for detection and verification of the relevant antigen. ENA tests are both diagnostically and prognostically significant because they support the detection of specific antigens especially in the diagnosis of rheumatological diseases such as SLE, Sjogren's Syndrome, Systemic sclerosis.

\section{ETHICS COMITTEE APPROVAL}

* The study was approved by Ondokuz Mayıs University Clinic Researchs Ethic Committee (Date: 01.10.2021 and Number: B.30.2.ODM.0.20.08/579).

\section{CONFLICT OF INTEREST}

The authors declare no conflict of interest.

\section{REFERENCES}

1. Smeenk RJ. Antinuclear antibodies: cause of disease or caused by disease? Rheumatology, 2000;39(6):581-4.

2. Yılmaz Ö, Karaman M, Ergon MC, Bahar ïH, Yuluğ N. Konnektif doku hastalıklarının tanısında Antinükleer (ANA) veAnti-doublestran-ded DNA (anti-dsDNA) antikorlarının önemi. T Parazitol Derg, 2005;29:287-290.

3. Afșar I, Şener AG, Vural A, Hızlı N, Türker M. Anti nükleer antikorların pozitif saptandığı hastalarda immunoblotting test sonuçlarının değerlendirilmesi. Türk Mikrobiyol Cem Derg, 2007;37(1):39-42.
4. Meroni PL, Schur PH. ANA screening: an old test with new recommendations. Ann Rheum Dis, 2010;69:1420-2.

5. Au EY, Ip WK, Lau CS, Chan YT. Evaluation of a multiplex flow immunoassay versus conventional assays in detecting autoantibodies in systemic lupus erythematosus. Hong Kong Med J, 2018;24(3):2619.

6. Us D, Şener B, Hasçelik G, Günalp A. Investigation of the Presence of Antibodies to Extractable Nuclear Antigens (Anti-ENA) by Immunoblot Techniquen in Systemic Lupus Erythematosus Patients. Mikrobiyol Bul, 1997;31:155-63. 
7. Damoiseaux JG, Tervaert JW. From ANA to ENA: How to Proceed? Autoimmunity Reviews, 2006;5(1):10-7.

8. Arnett FC, Edworthy SM, Bloch DA, McShane DJ, Fries JF, Cooper NS, et al. The american rheumatism association 1987 revised criteria for the classification of rheumatoid arthritis. Arthritis Rheum, 1988;31:315 - 24.

9. Vitali C, Bombardieri S, Jonsson R, Moutsopoulos HM, Alexander EL, Carsons SE, et al. Classification criteria for Sjogren's syndrome: a revised version of the European criteria proposed by the AmericanEuropean Consensus Group. Ann Rheum Dis, 2002;61:554 - 8 .

10. 1Watson RM, Lane AT, Barnett NK, Bias WB, Arnett FC, Provost TT. Neonatal lupus erythematosus. A clinical, serological and immunogenetic study with review of the literature. Medicine (Baltimore), 1984;63:362-78.

11. Singsen BH, Akhter JE, Weinstein MM, Sharp GC. Congenital complete heart block and SSA antibodies: obstetric implications. Am J Obstet Gynecol, 1985;152:655-8.

12. Hu PQ, Fertig $\mathrm{N}$, MedsgerJr TA, Wright TM. Correlation of serum anti-DNA topoisomerase I antibody levels with disease severity and activity in systemic sclerosis. Arthritis Rheum, 2003;48:136373.

13. Güdücüoğlu H, Yaman G, Çıkman A, Çalıșır U, Berktaș $M$. Retrospective evaluation of immunoblotting (IB) test results in anti-nuclear antibody positive patients. Turkish J Clin Lab, 2011;2:59-62.

14. Górniak G B, Rogacka N, Puszczewicz M. Antinuclear antibodies in healthy people and non-rheumatic diseases - diagnostic and clinical implications. Reumatologia, 2018; 56, 4: 243-8.
15. Li QZ, Karp DR, Quan J, Branch VK, Zhou J, Lian $Y$, veark. Risk factors for ANA positivity in healthy persons. Artritis Res Ther, 2011;13(2):R38.

16. Mengeloğlu Z, Taș T, Kocoglu E, Aktaș G, Karabörk $S$. Determination of anti-nuclear antibody pattern distribution and clinical relationship. Pak J Med Sci, 2014;30:380-3.

17. Çelikbilek N, Özdem B, Açıkgöz ZC. Evaluation of Anti-Nuclear antibody test results in clinical practice. J Microbiol Infect Diseas, 2015;5(2):63-8.

18. Karakeçe E, Atasoy AR, Çakmak G, ve ark. Bir üniversite hastanesinde antinükleer antiko rpozitiflikleri. Turk J Immunol, 2014;2:58.

19. Aktar GS, Ayaydın Z, Onur AR, Vural DG, Temiz H. Bir Eğitim ve Araștırma Hastanesinde IFA Yöntemiyle Çalıșılan Otoantikor Sonuçlarının Retrospektif Olarak Değerlendirilmesi. Turk J Immunol, 2017; 5(3)77-81.

20. Agmon-Levin N, Damoiseaux J, Kallenberg C, Sack U, Witte T, Herold $M$, et al. International recommendations for the assessment of autoantibodies to cellular antigens referred to as anti-nuclear antibodies. Ann Rheum Dis, 2014;73:17-23

21. Kaklıkkaya $N$, Akıneden A, Topbaș $M$, Aydın F. Determination of anti-nuclear antibody seroprevalence in adult age groups in Trabzon province. Balkan Med J, 2013;30:343-4

22. Evrensel N, Arslan F, Gödekmerdan A. Antinükleer antikorların retrospektif olarak değerlendirilmesi. 2. Ulusal Klinik Mikrobiyoloji Kongresi. Kasım, 1013, Antalya-Türkiye. 2013

23. Yumuk Z, Çalıșkan Ş, Gündeș S, Willke A. AntiNükleer antikorların araștırılması ve saptanmasında kullanılan teknikler. Türk Mikrobiyol Cem Derg, 2005;35(1):40-4 